\title{
Socio-Economic Contribution of Rift Value Aquatic and Wetlands to the Local Community and the National Economy: The Case of Lake Hawassa and Associated Wetlands, in the Southern Part of Ethiopia
}

\author{
Getaw Yilma* \\ Ethiopian Environment and Forest Research Institute, Ethiopia
}

Submission: November 14, 2019; Published: December 02, 2019

*Corresponding author: Getaw Yilma, Ethiopian Environment and Forest Research Institute, P.O. Box: 24536 (Code 1000), Addis Ababa, Ethiopia

\begin{abstract}
Wetlands are one of the most productive ecosystems that play a significant role in providing multiple ecosystem services. However, this resource has got less attention in national and regional planning. Hence, the objective of this study was to figure out the socioeconomic contribution of Lake Hawassa for the local and national economy and call for the concerned body (like; policymaker and planner) take possible action will be measured the lake from further degradation. A total of 164 households' questionnaires collected from five kebeles, and thus households were selected randomly from each kebele. Then, the data were analyzed using descriptive statistics, ANOVA and linear regressions model. The result showed that the majority of households' livelihood income strategies were from irrigation (54.8\%), rain-fed (33.8\%), livestock (6.5\%), fishing (3.5), off-farm seasonal work (1.2) \& others (0.2). The average annual total household income was 53,716.39 ETB. Out of this, lake income constituted $59.7 \%$ of the total income. The local households' income contribution of Lake Hawassa within selected kebeles was statistically significantly different by livestock watering, pasture for grazing animals and water for washing body or close. Other are did not reveal significant differences among the five kebeles for all the parameters analyzed. Overall result confirmed that the Lake contributed significantly to the household economy of the local people and hence, it is important to protect and improve the management of the lake and its wetlands for livelihood enhancement, while also securing their long-term ecological functions.
\end{abstract}

Keywords: Degradation; Driving factor; Ecosystem service; Household income; Livelihood strategies; Rrestoration; Wetland

\section{Introduction}

Wetlands are areas of marsh, ponds, and swamps, whether natural or artificial, permanent or temporary, with water that is static or flowing, fresh, brackish or salty, including areas of marine water, the depth of which at low tide does not exceed six meters [1-3]. Ethiopia is endowed with rich wetland resources that include lakes, marshes/swamps, rivers, flood plains, reservoirs, manmade ponds and dams [4]. These wetlands are located in almost all ecological and altitudinal ranges covering approximately $2 \%\left(22,600 \mathrm{~km}^{2}\right)$ of the country's total surface area [5,6]. If water bodies are included, in ANRS $3.7 \%$ is covered by wetlands, with 288,744 ha covered by swamps and marshes, and 316,609 ha by water bodies [6]. Some of the major wetlands and aquatic bodies of the Rift Valley basin are Ziway, Abjatata, Shalla, Langano, Hawassa, Abaya, Chamo and Chew Bahir and drain an area of about $52,000 \mathrm{Km}^{2}$ [7]. A total of 77 wetlands have been identified in Ethiopia and Eritrea [8].

Currently, the importance of the wetland ecosystem to the local communities in terms of social, economic and environmental values receives great public attention. Most of Ethiopia's aquatic and wetlands are providing broad socioeconomic benefits and ecological functions for so long time [9]. Among the wide range of socio-economic and ecological benefits, including the supply of food, water, furniture, pasture (grazing area for cattle), construction and fuel wood, raw materials for making household furniture, fodder, and medicine to rural communities, waste treatment and other several ecological services such as microclimate stabilization and serve as a carbon sink [10]. Economically, there are many development projects, which aimed on using the water and land resources sustainably, and thereby improve the livelihood of the people through various activities such as fishing, irrigation, handcraft making, livestock raring, collecting wood fuel wood for domestic purpose, agriculture, forestry, tourism, and as a mechanism for adapting droughts [11-14]. Further to their economic values, Ethiopian wetlands are historical, cultural and ritual importance $[15,16]$, and a large number of societies are depending on these wetlands for their livelihood [17]. 
According to MEA [10], wetlands ecosystem services are divided in to four main parts; the provisioning (food, freshwater, fiber and fuel, biochemical, animal feed, medicinal plants, genetic material, income and house construction material, and transportation), regulating (climate regulation, water regulation, water purification, retention of sediments and pollutants, flood and erosion regulation, natural hazard regulation and habitat for pollinators), cultural (spiritual and inspirational, recreational, aesthetic and educational) and supporting (soil formation, nutrient cycling, and carbon sequestration server as migratory routes for animals and habitat for flora and fauna). Wetlands of Ethiopia have also a great biological significance in terms of harboring a huge amount of biodiversity, particularly endemic, globally endangered and vulnerable bird species [18].

Lake Hawassa is one of many Ethiopian wetland resources. It lies near the town of Hawassa in the middle of a series of rift valley lakes and multiple social, cultural and ecological values for the local community. Furthermore, the town of Hawassa is famous and attractive primarily due to the lake. The town and the lake are celebrated resorts for local and foreign visitors. The magnificent views of the lake from resort hotels together with the many precious water birds make the wetland one of the country's most renowned tourism Center.

However, despite their values, Hawassa Lake is polluted [19] and the associated wetlands are caught in a spiral of degradation and fragmentation [8]. Until know, aquatic and wetlands in Ethiopia and elsewhere in the Horn have had less attention in the national as well as regional planning, their potential to enhance the local and national economy has been overlooked, and they provide multiple economic, social, cultural, and ecological functions and services which are crucial for the local, national and global society has been not well addressed [20]. Therefore, this study to figure out the ecosystem service in terms of socioeconomic contribution of Lake Hawassa and the associated wetlands for the local community and the national economy and call for policymakers, planners and natural resource managers take an action the landscape level, before further degradation of the resource. In this regard, this article is timely to understand the problems of Lake Hawassa and associated wetland are facing, and its possible action will be taken.

\section{Material and Methods}

\section{Description of the study area}

The study site is situated in the middle of a series of rift valley lakes at an altitude of 1680 M.a.s.l and $275 \mathrm{~km}$ south of Addis Ababa. Lake Hawassa lies to the west of Hawassa town, the capital of the Southern Nation Nationalities and Peoples' Regional State. The study sites (kebeles) are directly connected from western parts of the lake. The locations of each kebeles demonstrate in Figure 1. The area receives a mean annual rainfall of $950 \mathrm{~mm}$ and has a mean annual air temperature of $19.8^{\circ} \mathrm{C}$. The lake has a patch of wetlands and its surface area of $90 \mathrm{~km} 2$, a volume of $1.036 \times 109 \mathrm{~m}^{3}$ and a drainage area of $1,259 \mathrm{~km}^{2}(2018$ Google earth map). It is a terminal lake with no reported outflow. Compared to other rift lakes, the water is relatively dilute probably due to some sort of subterranean inflow, dilution from the feeder Tikur Wuha River and past basin overflow.

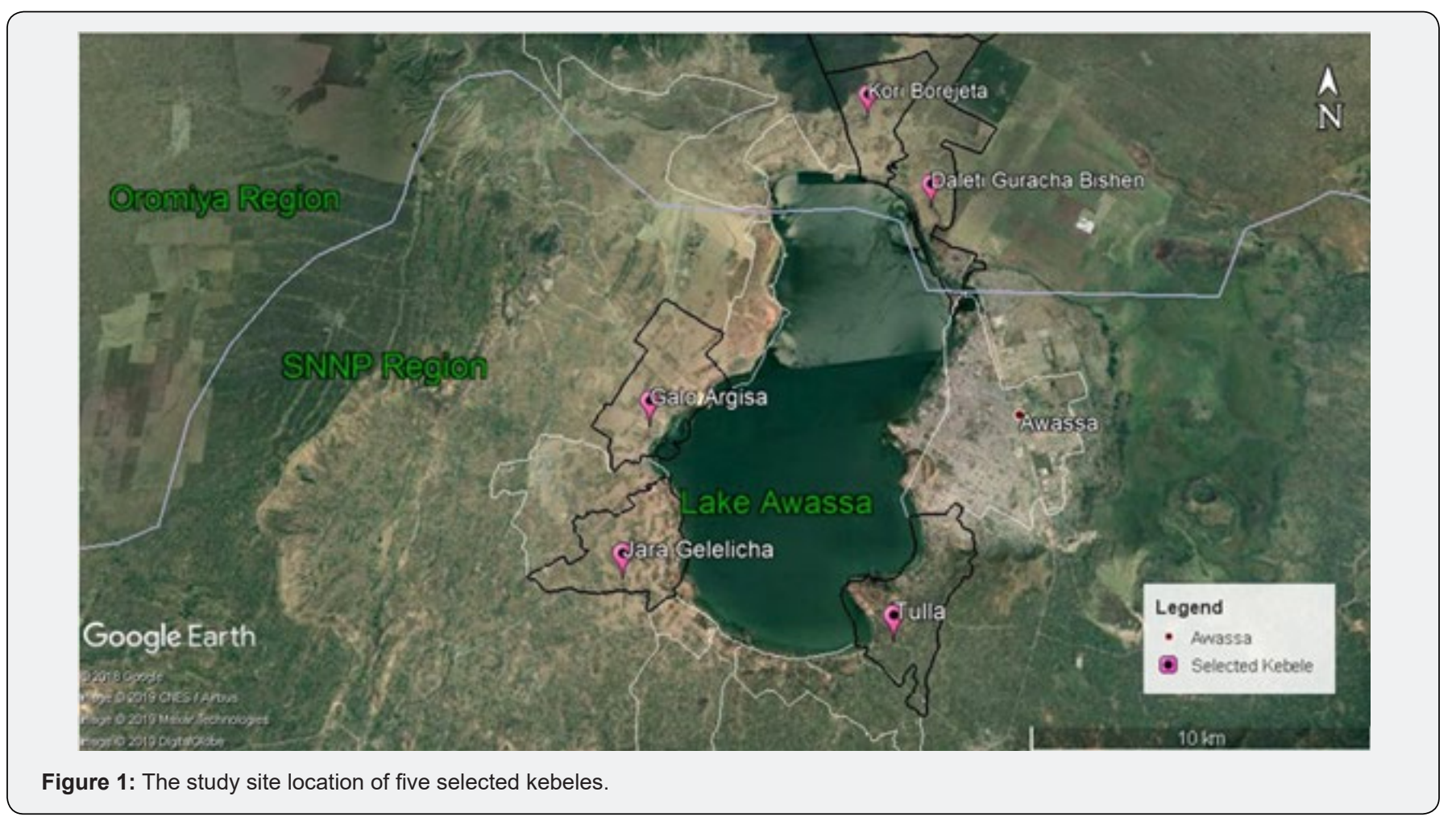


The communities of surrounding lakes have utilized the resources as a source of livelihood income. Northern, central and southern parts of the land scopes are manly agricultural lands populated by smallholder and mechanized commercial farms. The water of the lake is used for irrigation, bathing, recreation and drinking water for domestic use and wildlife. The fishery of the lake supplies vital fish protein and income for the people of the area and beyond. The wetland yields grass and other vegetation on which cattle may be grazed, boats constructed ('tankua'), mattresses, mats and agricultural implements created, and houses built. The major soil types within the catchment include cambisols, vertic Cambisols, andosols, vertic luvisols, Regosols, greysols, alisols, and leptosols. Furthermore, the town of Hawassa is famous and attractive primarily due to the lake.

\section{Sampling and economic evaluation methods}

Random sampling was employed to select study kebeles and respondents. Five administrative kebeles i.e., Daleti, cheleleka, Galo Argisa, Tulla, and Gelelcha, out of eleven rural kebeles were selected directly connected to the lake. A total of 164 households were randomly selected for a household survey. In addition, 40 individuals (i.e. 8 households from each kebele) participated in a focus group discussion and 15 key informants (i.e. 5 households from each kebele) were purposely selected for an in-depth case study and interviews. Population sampling followed procedures described in Campbell et al. [21] and Zenteno et al. [22].

The economic methods used to value wetlands are no different from the methods used to value any other type of environmental asset. These include market value approaches (which rely on quantification of production), surrogate market or revealed preference approaches (which rely on observation of related behavior) and simulated market or stated preference approaches (which rely on direct questioning). The simpler methods produce a total value, whereas those that involve the construction of models are better for estimating marginal values (the additional value generated by each unit of production) [23].

\section{Research design}

The reconnaissance field survey was made to obtain an overview of the study site, followed by a detailed preliminary survey, which was made between the $4^{\text {th }}$ weeks of January to the end of February 2017. Guided by principles of social-ecological co-evolution theory [24] and mixed quantitative and qualitative research design [25] was employed to collect data.

\section{Data collection}

For this study, an integrated qualitative and quantitative approach method was used. The primary data were collected through a household survey, focus group discussions, key informant interviews and a guided transect walk for observation $[21,26]$. A structured questionnaire that includes both closed and open-ended were designed and employed to generate quantitative and qualitative data from respondents. The main secondary data sources that were used in this research were both hard copies and online materials such as published and unpublished; articles, proceedings, project reports and other data available at district, zonal, regional, national and international levels. Pre-testing of the questionnaire was conducted to see about inclusiveness, its validity, relevance, and comprehensiveness. Based on the pre-testing feedback, the final questionnaire was prepared and administered accordingly. Data were collected on a number of variables including household characteristics, livelihood strategies, household assets, lake contribution to the local and national economy, income composition, expenditure and preference of lake water management system.

\section{Data analysis}

The Statistical Package for Social Scientists (SPSS) version 20.0 software was employed to analyze data drawn from the household survey. The data were analyzed using descriptive statistics and ANOVA. Descriptive statistics like mean, percentage and frequency distribution were used to analyze quantitative data. ANOVA used to test the significant difference of lake contribution between selected kebeles. Moreover, data were analyzed using the linear regressions model. A linear regression model (MLM) is one of econometric model mainly helps to analyze the dependent variables which are numerical data with the other independent variables which are either categorical or continuous. This model was used to analyze factors influence for income contribution of sample households from Lake Hawassa. The secondary sources used for narrative description and interpreted on spot.

\section{Result and Discussion}

\section{Result}

\section{Demographic characteristics of sampled households}

The structured questionnaire was administrated to a total of 164 household heads. Of this, the socio-demographic information showed that majorities of the sampled households (79.9\%) were male-headed, while the rest were female-headed (Table 1). This shows that male-headed households highly dominated female-headed households in the surveyed area. On the other hand, the mean respondents' age was 37 with a minimum and maximum of 18 and 85, respectively (Table 1 ). Regarding the level of literacy, the results showed that still low penetration of the formal education system. Only $11.6 \%$ of studied in the secondary level of education and near to one fourth $(24.4 \%)$ of interviewed households didn't follow formal education to write and read. Others, constituting $62.8 \%$ have got access to the attended primary level of education (Table 1 ). On the other side, the mean family size of the surveyed households was 6.77 with a minimum and maximum of 1 and 21, respectively. The result show that, the mean landholding size of each household had 1.1 with a range of 0.05-11 hectare, and land use type composition (\%) were; rain-fed (49.3), Irrigation (20.4), both (11.9), Wood 
lot (1.5), Grazing land (15.2) and Closure area (1.9). The majority of surveyed households' livelihood income strategies were from irrigation (54.8\%), rain-fed (33.8\%) and livestock (6.5\%). The composition of livestock species (\%); cattle (56.7), Goat (19.2) Sheep (10.3), Donkey (9.8) \& others (10.1) were reported by households in the study areas (Table 1). It is important information to know the demographic characteristics of the local community for policymaker, planer and natural resource manager to manage, sustainable utilization, and restoration of the lake at local, regional and national levels.

Table 1: Socio-economic characteristics of the sampled households.

\begin{tabular}{|c|c|}
\hline Socio-economic Characteristics & Descriptions \\
\hline Gender & Male: $79.9 \%$ and Female: $20.1 \%$ \\
\hline Age & Mean: 37 and Range: $18-85$ \\
\hline Literacy level & Illiterate: $24.4 \%$; Primary: 62.8\%; Secondary: $11.6 \%$ \& Diploma (1.2\%) \\
\hline Family size & Mean: 6.77 and Range: $1-21$ \\
\hline Land holding size (Ha) & Mean:1.1 and Range: 0.05-11 \\
\hline Land-use type composition (\%) & $\begin{array}{l}\text { rain-fed (49.3), Irrigation (20.4), Both (11.9), the Wood lot (1.5), Grazing land (15.2), Closure } \\
\text { area (1.9) }\end{array}$ \\
\hline Households' income livelihood strategies (\%) & $\begin{array}{l}\text { rain-fed (33.8), Irrigation (54.8), Livestock (6.5), Fishing (3.5), Off-farm seasonal work (1.2) \& } \\
\text { Others (0.2) }\end{array}$ \\
\hline Livestock composition (\%) & Horse (0.9), Cattle (56.7), Goat (19.2), Sheep (10.3), Donkey (9.8) \& Others (10.1) \\
\hline Religions (\%) & Muslim (40.2), Orthodox (4.9), Protestant (50.6), Catholic (1.2) \& Others (3) \\
\hline
\end{tabular}

Income contribution of Lake Hawassa for the local and national economy

The households' income sources from the lake could be categorized under irrigation production (52.3\%), livestock watering (10.0\%), Fish for Sale (7.2\%), water for domestic purposes $(7.1 \%)$ and others (Table 2). The average annual

household income from irrigation was $35120.45 \pm 114066.67 \mathrm{ETB}$ and this was the major total household income (54.8\%) of the study area. Other high household income next to irrigation was Wage or daily laborer salary (11957.14 $\pm 13647.018 \mathrm{ETB})$ and fish for sale (9710.32 $\pm 11527.25 \mathrm{ETB})$ respectively, and least household was getting from tourism $(1250 \pm 1060.66$ ETB) (Table 2).

Table 2: The type of income they have got due to the presence of Lake Hawassa.

\begin{tabular}{|c|c|c|c|c|c|c|c|}
\hline Income Source & Type of ESs & $\mathrm{N}$ & $\begin{array}{l}\text { Economic } \\
\text { Valuation } \\
\text { Approaches }\end{array}$ & $\begin{array}{l}\text { Minimum Income } \\
\text { (Year/ ETB) }\end{array}$ & $\begin{array}{l}\text { Maximum Income } \\
\text { (Year/ETB) }\end{array}$ & $\begin{array}{l}\text { Average Income } \\
\text { (Year/ ETB) }\end{array}$ & Std. Deviation \\
\hline Farming/irrigation & $\begin{array}{l}\text { Provision } \\
\text { service }\end{array}$ & 62 & Market value & 100 & 900000 & $35,120.45$ & 114066.7 \\
\hline Wage/salary & $>>$ & 14 & Stated preference & 800 & 48000 & $11,957.14$ & 13647.02 \\
\hline Husbandry/fishing & $>>$ & 6 & $>>$ & 1500 & 35000 & $10,903.33$ & 12543.05 \\
\hline Fish for sale & $>>$ & 31 & $>>$ & 400 & 50000 & $9,710.32$ & 11527.25 \\
\hline Sand for sale & $>>$ & 9 & $>>$ & 2500 & 20000 & 7277.78 & 5662.989 \\
\hline $\begin{array}{l}\text { Fertile land for crop } \\
\text { growing }\end{array}$ & $>>$ & 2 & $\begin{array}{l}\text { Change } \\
\text { production }\end{array}$ & 4800 & 5000 & 4900 & 141.421 \\
\hline Livestock watering & $>>$ & 102 & $>>$ & 60 & 200000 & 4082.36 & 20441.9 \\
\hline $\begin{array}{l}\text { Fish for household } \\
\text { feeding }\end{array}$ & $>>$ & 101 & Stated preference & 120 & 72000 & 2811.42 & 7414.602 \\
\hline $\begin{array}{l}\text { Water for domestic } \\
\text { purpose }\end{array}$ & $>>$ & 109 & Market value & 96 & 100000 & 2728.73 & 9810.983 \\
\hline Firewood for cooking & $>>$ & 19 & Market value & 250 & 5000 & 2459.47 & 1560.016 \\
\hline Wild fruit trees & $>>$ & 5 & Market value & 120 & 5000 & 2369 & 2422.768 \\
\hline Honey for bee keeping & $>>$ & 11 & Market value & 150 & 6000 & 2179.09 & 1758.354 \\
\hline $\begin{array}{l}\text { Wood and wood } \\
\text { product }\end{array}$ & $>>$ & 1 & Market value & 2000 & 2000 & 2000 & . \\
\hline Medicinal plants & $>>$ & 1 & Stated preference & 2000 & 2000 & 2000 & . \\
\hline Grasses & $>>$ & 42 & Market value & 100 & 12000 & 1909.17 & 2374.391 \\
\hline
\end{tabular}




\section{International Journal of Environmental Sciences \& Natural Resources}

\begin{tabular}{|c|c|c|c|c|c|c|c|}
\hline $\begin{array}{c}\text { Pasture for grazing } \\
\text { animals }\end{array}$ & $>>$ & 34 & Market value & 300 & 9600 & 1891.82 & 1849.177 \\
\hline Washing body or close & $>>$ & 98 & $\begin{array}{c}\text { Change } \\
\text { production }\end{array}$ & 96 & 10080 & 1354.88 & 2050.527 \\
\hline Tourism & $\begin{array}{c}\text { Cultural } \\
\text { service }\end{array}$ & 2 & Market value & 500 & 2000 & 1250 & 1060.66 \\
\hline Sand for construction & $\begin{array}{c}\text { Provision } \\
\text { service }\end{array}$ & 13 & Market value & 100 & 4000 & 1130.351 \\
\hline Firewood for sale & $>>$ & 0 & Market value & & & & \\
\hline $\begin{array}{c}\text { Trading/providing } \\
\text { hand Crafts for tourists }\end{array}$ & $>>$ & 0 & Market value & & & \\
\hline Poles for construction & $>>$ & 0 & Market value & & & \\
\hline
\end{tabular}

ESs stands for Ecosystem service and ETB stands for Ethiopian Birr.

The income contribution of Lake Hawassa for the local households was statistically significantly different between selected kebeles by livestock watering, pasture for grazing

animals and water for washing body or close. Other are did not reveal significant differences among the five kebeles for all the parameters analyzed (Table 3).

Table 3: households' income contribution of Lake Hawassa in selected kebeles.

\begin{tabular}{|c|c|c|c|c|c|c|}
\hline Income Source of Lake & $\begin{array}{l}\text { Cheleleka (year/ } \\
\text { birr) }\end{array}$ & $\begin{array}{l}\text { Daleti (year/ } \\
\text { birr) }\end{array}$ & $\begin{array}{l}\text { Galo Argisa } \\
\text { (year/birr) }\end{array}$ & $\begin{array}{l}\text { Gelelcha (year/ } \\
\text { birr) }\end{array}$ & Tulla (year/birr) & Sig. \\
\hline wage/salary & 4800 & 7000 & 3600 & 4200 & 18914.29 & 0.505 \\
\hline Irrigation & & & 56136.65 & 24027.08 & 13726.5 & 0.814 \\
\hline Legal fisherman & & 5000 & & 7973.33 & 18250 & 0.696 \\
\hline Grasses for livestock fodder & 110 & & 1330.29 & 2121.88 & 3342.86 & 0.184 \\
\hline Wild fruit trees & & & 2780 & 725 & & 0.529 \\
\hline Water for domestic purpose & 6540.69 & 3028.57 & 1229.88 & 882.31 & 2106.89 & 0.177 \\
\hline Livestock watering & 5517.92 & 25692.5 & 903.24 & 1340.5 & 1135 & $0.029 *$ \\
\hline Fish for house hold feeding & 4931.2 & 2900 & 1424.62 & 1572.03 & 4700 & 0.343 \\
\hline Fish for sale & 13600 & 9000 & & 7510 & 6620 & 0.58 \\
\hline Honey beekeeping & 883.33 & 800 & & 2704 & 3500 & 0.31 \\
\hline Sand for construction & 700 & & & 1900 & 1250 & 0.228 \\
\hline Sand for sale & & 8666.67 & & 6583.33 & & 0.636 \\
\hline Pasture for grazing animals & 2666.67 & 1000 & 1473.47 & 1687.14 & 9600 & $0.00 *$ \\
\hline Fire wood for cooking & 2320 & 3500 & 2675 & 1816.67 & 1800 & 0.789 \\
\hline $\begin{array}{c}\text { Water for washing body or } \\
\text { close }\end{array}$ & 2487.59 & 1296.36 & 385.55 & 838.46 & 1609.6 & $0.002 *$ \\
\hline
\end{tabular}

* indicates the significance at $p=0.01$. ETB stands for Ethiopian Birr.

The other important question is which variables (i.e. Age, Family size, Sex, Educational status, and Kebele) affect the income contribution of Lake Hawassa, and the results indicated that the total annual income and lake income contribution of the sample households there was no statistically influenced by kebeles, Age, sex and education status. Only sex was affected other (i.e. the sum of wage/salary, Wood and wood product, Grasses, Wild fruit trees, Water for domestic purpose, Livestock watering, Medicinal plants, Fertile land for crop growing, Honey for beekeeping, Sand for construction, Sand for sale, Pasture for grazing animals, Firewood for cooking, Washing body or close, Tourism) income contribution of the lake. The factors which affect for statistically significant at alpha 0.05 significance level as shown in Table 4.
Table 4: Factors of total annual income and lake annual income contribution of lake.

\begin{tabular}{|c|c|c|c|c|c|}
\hline \multirow{2}{*}{$\begin{array}{c}\text { Explanatory } \\
\text { Variables }\end{array}$} & \multirow{2}{*}{$\begin{array}{c}\text { Total } \\
\text { Annual } \\
\text { Income }\end{array}$} & \multicolumn{3}{|c|}{ Lake Annual Income Contribution } \\
\cline { 3 - 6 } & Irrigation & Fishery & Others & Total \\
\hline Kebeles & 0.453 & 0.421 & 0.263 & 0.585 & 0.813 \\
\hline Age & 0.929 & 0.566 & 0.124 & 0.139 & 0.509 \\
\hline Family Size & 0.772 & 0.897 & 0.106 & 0.336 & 0.843 \\
\hline Sex & 0.792 & 0.704 & 0.688 & $0.019^{*}$ & 0.811 \\
\hline $\begin{array}{c}\text { Educational } \\
\text { status }\end{array}$ & 0.484 & 0.859 & 0.468 & 0.325 & 0.769 \\
\hline
\end{tabular}

Figures in the table indicate $p$-value $(p=0.01)$ from the linear regression model. 


\section{Discussion}

The main livelihood strategy of the local community is agriculture, mainly from the irrigation. This finding similar to the Shewit et al. [27] study, which stated that the backbone of development in Ethiopia is agriculture and this activity, is mainly practiced at the expense of the aquatic resources, particularly wetlands. A similar study in rift valley Lake Ziway was the average annual household income from irrigation [28]. In Ethiopia irrigation and fishery is the most common source of income along with living near or the borders of the lake Tenalem [29], Tenalem \& Degnachew [30], Spliethoff et al. [31] and Chance [32]. However, in the cause of Lake Hawassa, wages or daily laborer are high individual incomes than fishery because of high-quality sand accumulation in the lake and the local community to dig out those sands for the investor with good pay, and these views also support by Wondie [33].

The importance of this study, to show the ecosystem service (only some of the provisioning and cultural service) were converted into monetary value for the local and national economy because of the total economic value of unconverted wetlands is often greater than that of converted wetlands [34]. While it can be difficult to calculate the economic value provided by a single wetland, there are some ways of the ecosystem service of wetlands that are converted into monetary values. For instance, areas of intact mangroves wetlands in Thailand have a total net present economic value calculated based on the economic contribution of both marketed products such as fish and non-marketed services such as protection from storm damage and carbon sequestration at the range of $\$ 1,000$ $\$ 36,000$ per hectare compared with about $\$ 200$ per hectare when converted to shrimp farms [34]. Thus, result showed that the total economic values of protected wetlands are at least five times greater than that of converted wetlands. They serve to slow down storm flood, trap sediments, protect property damage in downstream, and the siltation of dams [35]. A global value for ecosystem goods, services, biodiversity, and cultural considerations of US\$ 6,579x109 year-1 has been estimated for all inland waters and wetlands in comparison to US\$ 5,740x109 year-1 for all other non- marine ecosystems combined [17]. Globally, the monetary value of ecosystem services provided by all wetland's amounts can be impressive. According to one assessment of natural ecosystems, the dollar value of wetlands worldwide was estimated to be $\$ 14.9$ trillion [36]. This fact thus studies the value of wetlands contributes to the economy.

Furthermore, the importance of this study point towards to develop our country a Natural Resource Accounts (NRA) for endowed wetland resources. You know a country's economic performance is measured in terms of its national income and asset base, and the average income per capita is a common indicator of societal wellbeing. National income is calculated in the National Accounting process, which generates various measures of income such as Gross Domestic Product (GDP), Net
Domestic Product (NDP) or Net National Product (NNP). The National Accounts quantify the value of capital assets and the annual value of production at a national scale. As a supplement to the national accounts, many countries have now also developed a number of Natural Resource Accounts (NRA) for various natural assets such as water and minerals [37]. The NRA production accounts measure the use-value, in terms of contribution to Gross National Product, of the natural resources each year, and as such are normally included in the national accounts. The NRA asset accounts measure the value of natural resource stocks as capital assets [23].

Generally, Lake has greatly contributed ecosystem service in terms of monetary value (directly/ indirectly) for local and national economy, this include provisioning service (irrigation, fishery, Wage/salary, Wood and wood product, Grasses, Wild fruit trees, Water for domestic purpose, Livestock watering, Fish for household feeding, Fish for Sale, Medicinal plants, Fertile land for crop growing, Honey for beekeeping, Sand for construction, Sand for sale, Pasture for grazing animals, Firewood for cooking, Washing body or close), cultural service (Tourism), and other non-monetary value (regulating and supporting service). Similar findings are stated in terms of ecosystem service [8] and wetlands in the Lake Tana [33]. Generally, wetlands are provide a host of ecosystem services that benefit their surrounding populations, such as flood control, water purification, sediment and nutrient retention, dry season grazing, agriculture, microclimate stabilization, recreation and cultural values, water supply (domestic and livestock), construction (thatching reeds), medicine, and habitat for birds [27,38]. Ethiopia has 73 important bird area 'hot spots', of which 43 are wetlands that provide shelter to endemic, globally endangered, vulnerable and near-threatened bird species $[39,40]$. These habitats are becoming increasingly recognized as among the most productive natural resource $s$, because of their ability to fulfill a range of functions and produce a number of products that are socially and economically beneficial to the local community [41]. Ecologically, wetlands are instrumental in water storage, filtration, and supply, flood control; perform sediment, nutrient and retention functions and habitats for the biodiversity of both flora and found [8].

\section{Conclusion}

Wetlands provide multiple economic, social, cultural, and ecological functions and services that are crucial for the local, national and global society. Even though researchers have paid a great deal of attention to wetland loss and status, the actual extent of wetland loss on a global scale, especially the loss caused directly by human activities, and the actual extent of currently surviving wetlands remains uncertain [42].

This study inspires the policymaker, local community, governmental and NGO bodies by figure out the ecosystem service in terms of monetary value; how much contribute to the local and national economy, the threatening factors and its 
possible action will be taken. This leads the governmental bodies to design appropriate policy intervention for its conservation mitigation, and restoration through economic value valuation methods. Because the lake is under high risk of deleterious anthropogenic activities and it needs more attention, effort, and commitment at all levels, from grassroots to decision and policymakers, in order to minimize and reverse the threats and to bring a sustainable solution to the problem [43-73].

\section{Acknowledgment}

The financial support from the Ethiopian Environment and Forest Research Institute (EEFRI) is highly acknowledged. We are grateful to all our staff colleagues specially Gezahegne seyoum and Wondmagegn Amanueal, Dorye Bafana and Shashemenye zuria Woreda Environment and Forest Protection office members who participated through data collection, analysis, and final edition of this manuscript. Last, but not least, my special thanks go to key informants and heads of surveyed households for their kind respect and support while collecting data.

\section{Funding}

The study was supported by the Ethiopian Environment and Forest Research Institute (EEFRI) through the provision of finance.

\section{References}

1. Ramsar Convention Bureau (1997) The Ramsar Convention Manual: A Guide to the Convention on Wetlands (Ramsar, Iran, 1971), ( $2^{\text {nd }}$ edn), Ramsar Convention. RCB, the Gland 170(1997).

2. Sivaperuman C, Jayson EA (2000) Birds of Kole Wetlands, Thrissur, Kerala: case report. Zoos' Print J 15(10): 344-349.

3. Kafle G (2006) Wetlands and Ramsar Sites. Wetland Educational Kit Series. Wetland

4. Leykun A (2003) The distribution and status of Ethiopian wetlands: an overview. In: Abebe YD, Geheb K (Eds.), Wetlands of Ethiopia, proceedings of a seminar on the resources and status of Ethiopia's wetlands, IUCN.

5. EPA (Ethiopian Environmental Authority) (2004) Proceedings of the National consultative Workshop on the Ramsar convention and Ethiopia. Addis Ababa, Ethiopia.

6. EWNRA (Ethiopian Wetlands and Natural Resources Association) (2008) Creating National Commitment for Wetland policy and Strategy Development in Ethiopia, Paper presented for proceeding of the National Stake holder's workshop, August 2008, Addis Ababa, Ethiopia.

7. Alemayehu $T$ (2006) Abstracts of the Founding Congress of the Ethiopian Association of Hydro Geologists (EAH). Addis Ababa.

8. Abebe YD, Geheb K (2003) Wetlands of Ethiopia. Proceedings of a seminar on the resources and status of Ethiopia's wetlands, p. 116.

9. EPA (Ethiopian Environmental Authority) (2002) Office Report on the Ethiopian Rift valley wetlands assessment.

10. MEA (Millennium Ecosystem Assessment) (2005) Ecosystems and Human Well-being: Wetlands and Water Synthesis, Millennium Ecosystem Assessment, MA. World Resources Institute, Washington, DC, USA.

11. Guillemette F, Plamondon AP, Prevost M, Levesque D (2005) Rainfall generated stormflow response to clearcutting a boreal forest:
Peak flow comparison with 50 worldwide basin studies. Journal of Hydrology 302(1-4): 137-153.

12. Handisyde NT, Ross LG, Badjeck MC, Allison EH (2006) The effect of climate change on world aquaculture: A global perspective. Final Technical Report by the Institute of Aquaculture, Sterling, UK and sponsored by the Department for International Development (DFID), p. 151.

13. Hefting MM, van den Heuvel RN, Verhoeven JT (2013) Wetlands in agricultural landscapes for nitrogen attenuation and biodiversity enhancement: Opportunities and limitations. Ecological Engineering 56: 5-13

14. Hillman J, Abebe D (1993) Wetlands of Ethiopia in Ethiopia: Compendium of Wildlife Conservation Information. NYZS the Wildlife Conservation Society International, New York Zoological Park, Bronx, NY and Ethiopian Wildlife Conservation Organization, Addis Ababa 2: 786.

15. Houghton JT, Ding Y, Griggs DJ, Noguer M, van der Linden, et al. (2001) Climatic change 2001: The scientific basis. Cambridge: Cambridge University Press, USA.

16. Jorge D, Farhed S, Boris B, Americo J, Jose M, et al. (2014) The external impact of agriculture on inland wetlands: A case study from Argentina. European Scientific Journal 10(17): 1857-7881.

17. Junk WJ, An S, Finlayson CM, Gopal B, Kvt J, et al. (2013) Current State of Knowledge Regarding the World's Wetlands and their Future under Global Climate Change: A Synthesis. Aquatic Sciences 75(1): 151-167.

18. Menbere IP, Menbere TP (2018) Wetland ecosystems in Ethiopia and their implications in ecotourism and biodiversity conservation. Journal of Ecology and the Natural Environment 10(6): 80-96.

19. Abate B, Woldesenbet A, Fitamo D (2015) Water quality assessment of Lake Hawassa for multiple designated water uses. Water Utility Journal 9: 47-60.

20. Giweta M, Worku Y (2018) Reversing the Degradation of Ethiopian Wetlands: Is it Unachievable Phrase or A Call to Effective Action? Int J Environ Sci Nat Res 555898.

21. Campbell BM, Jeffrey S, Kozanayi W, Luckert M, Mutamba M, et al (2002) House-hold Livelihoods in Semi-Arid Regions, Options and Constraints. CIFOR, Indonesia.

22.Zenteno M, Zuidema PA, Jong W, Boot René GA (2012) Livelihood strategies and forest dependence: new insights from Bolivian forest communities. Forest Policy and Economics 26: 12-21.

23. Turpie J, Lannas K, Scovronick N, Louw A (2010) Wetland ecosystem services and their valuation: a review of current understanding and practice.

24. Colding J, Folke C, Thomas E (2003) Social institutions in ecosystem management and biodiversity conservation. Tropical Ecology 44(1): $25-41$.

25. Creswell W (2009) Qualitative, quantitative and mixed Methods Approach, SAGE Publications; New Delhi, India.

26. Cavendish W (2003) How do forests support, insure and improve the livelihoods of the rural poor? A Research Note, CIFOR; Bogor, Indonesia.

27. Shewit G, Minwyelet M, Tesfaye M, Lewoye T, Ferehiwot M (2017) Land use change and its drivers in Kurt Bahir wetland, north-western Ethiopia. African Journal of Aquatic Science 42(1): 45-54.

28. Gezahegne S (2015) Willingness to Pay (WTP) for Ecosystem Goods and Services of Wetland (In case of Lake Ziway). International Journal of Scientific Research in Agricultural Sciences 2(8): 175-184.

29. Tenalem A (2004) Environmental implications of changes in the levels of lakes in the Ethiopian Rift Since 1970. Reg Environ Change 4(4): 
192-204.

30. Tenalem A, Degnachew L (2007) The changing face of the Ethiopian rift lakes and their environs: call of the time. Lakes Reserved Res Manage 12(3): 149-165.

31. Spliethoff P, Wudneh T, Tariku E, Senbeta G (2009) Past, Current and Potential Production of Fish in Lake Ziway-Central Rift Valley in Ethiopia. Capacity Development and Institutional Change Programme Wageningen International, Wageningen, the Netherlands.

32. Chance RU (2016) Plant communities of a wetland in western Ethiopia. MSc Thesis, University of Oslo, Norway.

33. Wondie A (2010) Improving management of shoreline and riparian wetland ecosystems: the case of Lake Tana catchment. Eco hydrology and Hydrobiology 10(2-4): 123-131.

34. François GGH, Marcelle GSL, Mooney HA, Cropper A, Leemans R, et al. (2005) Ecosystems and human well-being: wetlands and water. Regions and Cohesion (Vol. 13). Friends of Nepal, Institute of Forestry, Pokhara.

35. Amsalu T, Addisu S (2014) A review of Wetland Conservation and Management Policy in Ethiopian 4(9): 1-6.

36. Costanza R, Farber SC, Maxwell J (1989) Valuation and management of wetland ecosystems. Ecological Economics 1(4): 335-361.

37. Lange GM, Hassan R, Hamilton K (2003) Environmental Accounting in Action: Case Studies from Southern Africa. Edward Elgar Publishing, Cheltenham, UK, p. 223.

38. Lamsal P, Pant KP, Kumar L, Atreya K (2015) Sustainable livelihoods through conservation of wetland resources: a case of economic benefits from Ghodaghodi Lake, western Nepal. Ecology and Society 20(1): 10.

39. Ayinalem S (2007) Species composition, distribution, relative abundance and habitat association of the bird fauna of Bahir Dar, Zegie Peninsula and nearby islands. MSc thesis, Addis Ababa university.

40. Moges A (2008) Species composition, distribution, relative abundance and habitat association of avian fauna in Fogera Plain wetland. MSc thesis, Addis Ababa University, Ethiopia.

41. Dugan P (1990) Wetland Conservation: A Review of Current Issues and Required Action. IUCN Gland Switzerland 94.

42. Hu S (2017) Global wetlands: Potential distribution, wetland loss, and status. Sci Total Environ 586: 319-327.

43. Afework H, Enyew A, Fekadu Y (2005) Potential wetland resource of Ethiopia, use and threats: Proceedings of the wetland awareness creation and activity identification workshop in Amhara National Regional State.

44. Atnafu N, Dejen E, Silverberg J (2011) Assessment of the ecological status and threats of Welala and Shesher wetlands, Lake Tana sub basin (Ethiopia). Journal of Water Resource and Protection 3: 540-547.

45. Ayalew D (2003) Fisheries management: Ecosystem approach. EPA. In Tefetro (Ed.), A biannual Amharic English magazine, (Year 2, No.1). Addis Ababa, Ethiopia.

46. Ayenew T (2002) Recent changes in the level of Lake Abiyata, central main Ethiopian Rift. Hydrological Sciences Journal 47(3): 493-503.

47. Ayenew T (2009) Natural lakes of Ethiopia. Addis Ababa: Addis Ababa University Press.

48. Barbier E, Acreman MC, Knowler D (1997) Economic Valuation of Wetlands: A Guide for Policy Makers and Planners. Ramsar Convention Bureau, Switzerland, p. 127.

49. Barbier EB (1993) Sustainable use of wetlands valuing tropical wetland benefits: Economic methodologies and applications. The Geographical Journal 159(1): 22-32.
50. Bowers J (1983) Economics and conservation: The case of land drainage conservation in perspective. In: Warren A, Goldsmith FB (Eds.), John Wiley and Sons Ltd. pp. 375-389.

51.Eleni A (2009) Growing Lake with Growing Problems: Integrated Hydrogeological Investigation on Lake Beseka.

52. Gebrekidan W (2014) Assessment of the shrinkage and ecological importance of wetlands of Fogera Plain, north-west Ethiopia. Journal of Environment and Earth Science 4: 38-43.

53. Gebremedhin G, Belliethathan, S (2016) Socio-economic benefit of wetland ecosystem (in case of Lake Ziway). Preprints 2016070068.

54. Gebriye S, Srinivasan R, Dargahi B, Melesse A (2009) Spatial delineation of soil erosion vulnerability in the Lake Tana Basin, Ethiopia. Hydrological Processes 23(26): 3738-3750.

55. Gemechu BD (2010) The Challenges and Opportunities of Wetlands Management in Ethiopia: The Case of Abijiata Lake Wetlands. MSc Thesis in Addis Ababa University.

56. Hirpo LA (2018) The Effect of Wetland Degradation on Fish Production in Ethiopia. Int J Adv Res Biol Sci 5(2): 178-187.

57. International Water Management Institute (IWMI) (2014) Wetlands and people. Colombo, Sri Lanka: p. 32.

58. IWMI (International Water Management Institute) (2006) Working Wetlands: A New Approach to Balancing Agricultural Development with Environmental Protection, IWMI International Water Management Institute.

59. Kassaye B (2015) Hydrodynamics of Selected Ethiopian Rift Lakes. Civil and Environmental Research.

60. Lijalem Z (2007) Climate Change Impact on Lake Ziway Watershed Water Availability, Ethiopia.

61. Mengesha TA (2017) Review on the natural conditions and anthropogenic threats of Wetlands in Ethiopian. Glob J Ecol 2(1): 006014 .

62. Mengistu W (2003) Wetlands, birds and important bird areas in Ethiopia. In: Abebe YD, Geheb K (Eds.), Proceedings of a seminar on the resources and status of Ethiopia's wetlands, IUCN Wetlands and Water Resources Programme, January 2003, Addis Ababa, Ethiopia. Published by International Union for Conservation of Nature and Natural Resources (IUCN).

63. Mironga JM (2005) Effect of farming practices on wetlands of Kisii District, Kenya. Journal of Applied Ecology and Environmental Research 3: 81-91.

64. Moges A, Beyene A, Ambelu A, Mereta ST, Triest L, et al. (2016) Plant species composition and diversity in wetlands under forest, agriculture and land uses. Aquat Bot 138: 9-15.

65. Mohammed IB, Mengist M (2018) Status, Threats and Management of Wetlands in the Lake Tana Sub-basin: A Review. J Agric Environ Sci 3(2): $23-45$

66. Mulugeta D (2015) Characterization of Water Level Variability of the Main Ethiopian Rift Valley Lakes. Hydrology 3(1).

67. Tiner RW (1984) Wetlands of the United States: Current status and trends. Washington, D.C.: U.S. Fish and Wildlife Service.

68. Wood A (2001) The role and Importance of wetlands in Ethiopia. Proceeding of the Wetlands Awareness creation Workshop of the ANRS, Bahirdar, Ethiopia.

69. Wood A, Dixon A (2002) Sustainable wetland management in Illubabor zone: Research report summaries. The University of Huddersfield, Huddersfield.

70. Yasser AK, Al-Gahwari (2007) Thesis on Physico-chemical parameters 
and microorganisms as water quality indicators of Teluk Buhang Reservoir and Batu Ferringhi Treatment Plant. University Saints Malaysia.

71. Yilma A. (2003) Wetlands of Ethiopia: an introduction, In: Wetlands of Ethiopia. Proceedings of a seminar on the resources and status of Ethiopia's wetlands, Nairobi, Kenya, p. 116.

72.Zamora PM (1984) Philippine mangroves: assessment of status, environmental problems, conservation and management strategies. In: Soepadmo E, Rao AN, MacIntosh DJ (Eds.), Proceeding of Asian
Symposium on mangrove environment research and management, 25-29 August 1984, University of Malaya, Kuala Lumpur, Malaysia, pp. 606-707.

73. Zerihun D (2003) Challenges and opportunities of Ethiopian wetlands: the case of Lake Awassa and its feeders, Debub University, Awassa College, Awassa, Ethiopia.

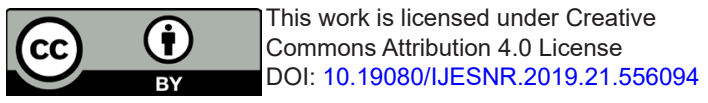

